\title{
Influence of the Sawing Method on Yield of Beech Logs with Red Heartwood
}

\section{Utjecaj načina piljenja na iskorištenje bukovih trupaca s lažnom srži}

\author{
Original scientific paper • Izvorni znanstveni rad \\ Received-prispjelo: 22. 2. 2013. \\ Accepted-prihvaćeno: 6. 2. 2014. \\ UDK: 630*822, 630*832.151; 674.031.632.224; 674.093:657.47 \\ doi:10.5552/drind.2014.1312
}

\begin{abstract}
The paper presents the research of differences in quantitative and value yields, and structure of sawn timber and residues, whose appearance is caused by different methods of sawing beech logs with red heartwood. In order to achieve the goal, 45 logs were divided into three even groups and sawn into commercial timber using three methods: round, cant and live sawing. Similar quantitative yields were found for round sawing and cant sawing (60.63\% and $60.52 \%$, respectively), while a lower result of $56.79 \%$ was observed for live sawing. Less timber (edged and red heartwood boards) and smaller products were found in live sawing than in other two methods, meaning that live sawing resulted in a lower value yield.
\end{abstract}

Keywords: beech, sawmill processing, methods of sawing, yield, red heartwood

\begin{abstract}
SAŽETAK • Prilikom prerade bukovih pilanskih trupaca s lažnom srži na primarnim pilanskim strojevima primjenjuju se različiti načini piljenja. Najčešće su to kružno piljenje, prizmiranje i piljenje ucijelo. Cilj istraživanja bio je da se u preradi bukove oblovine, pri izdvajanju lažne srži u zasebne sortimente (srčanice), utvrdi utjecaj načina primarnog piljenja na kvantitativno i vrijednosno iskorištenje, kao i na sortimentnu strukturu dobivenih proizvoda. Za istraživanje su odabrani bukovi pilanski trupci promjera 40 - $49 \mathrm{~cm}$, duljine $4 \mathrm{~m}$. Od uzorka koji je obuhvaćao 45 trupaca za primjenu navedenih načina piljenja formirane su tri ujednačene skupine od 15 trupaca. Istraživanje je izvedeno u industrijskim uvjetima. Trupci su primarno obrađeni tračnim pilama (trupčarom i paralicom) te je proizvedena piljena građa nominalne debljine 25 i $50 \mathrm{~mm}$. Sekundarna obrada provedena je poprečno-podužnopoprečnim postupkom, na strojevima za individualno piljenje, a sitni su sortimenti izrađivani na stolarskoj tračnoj pili i kratilici za popruge. Kvantitativno iskorištenje pri kružnom piljenju iznosilo je 60,63 \%, kod prizmiranja $60,52 \%$, a pri piljenju ucijelo 56,79\%. Nadmjera je bila približno $10 \%$. U sva tri načina piljenja udio krupnoga pilanskog ostatka bio je približno jednak udjelu piljevine. Kružnim je piljenjem dobivena najbolja kvaliteta sortimenata, ali i najveći udio srčanica. Prizmiranjem je dobiveno najviše piljene građe (ukupno - okrajčene $i$ neokrajčene), kao i najveća količina najvrjednijih sortimenata - duge okrajčene piljene građe. Piljenjem ucijelo nastalo je znatno više sitnih sortimenata (četvrtača i popruga) nego pri drugim načinima piljenja, ali i najmanje srčanica. U sva tri načina piljenja prevladavale su piljenice tangencijalne teksture, zatim one poluradijalne teksture, dokje radijalnih bilo najmanje i većinom su to bile srčanice. Kružnim piljenjem i prizmiranjem postignuto je približno jednako vrijednosno iskorištenje, dok je piljenje ucijelo dalo nešto lošije iskorištenje.
\end{abstract}

Ključne reči: bukva, pilanska prerada, načini piljenja, iskorištenje, lažna srž

\footnotetext{
${ }^{1}$ Authors are assistant, professor, assistant professor, assistant professor and assistant at University of Belgrade, Faculty of Forestry, Belgrade, Serbia.

${ }^{1}$ Autori su asistent, profesor, docent, docent i asistent Šumarskog fakulteta Sveučilišta u Beogradu, Beograd, Srbija.
} 


\section{INTRODUCTION}

\section{UVOD}

Beech is one of the most important wood species in Europe. One of its characteristics is red heartwood, which develops in the center of the tree and differs from outer wood (sapwood) by its red color. Knoke (2003) reported that the appearance and size of red heartwood was influenced by diameter, height and age of a tree, its branchiness, share of crown in total height of a tree and the width of growth rings, but that the greatest influence came from tree dimensions and age. Wernsdörfer et al. (2005) researched the relation between shape and size of red heartwood and stem external features (dead branches, branch scars, wounds, cracks, forks) and stated that the influence of scars was notable in some cases and that it was related to the size of the defect and the rate of entrance of oxygen into the tree.

The yield of beech round wood is related to the presence of red heartwood (Škaljić, 2002; Popadić and Todorović, 2009). In general, the yield of raw material, as well as the quality and dimensional structure of sawn products, depends on the method of sawing (Zubčević, 1973; Gregić, 1982; Skakić, 1985; Hapla and Ohnesorge, 2005), the quality of raw material (Petutschnigg and Katz, 2005; Šoškić and Milić, 2005; Šoškić and Popadić, 2007), the dimensions of the log (Zubčević, 1973; Tanušev et al., 2009), the board marker accuracy (Buehlmann and Thomas, 2002, 2007), the technology applied (Zubčević, 1973) and the choice between single-phase and two-phase technological process (Zubčević, 1973; Gregić, 1982; Skakić, 1985).

In recent years, there has been a certain demand for timber made from red heartwood. Designers use it to create unique products and, however, its presence is usually not tolerated in commercial interior products (Prekrat et al., 2004). Therefore, in sawmill process- ing, it is necessary to separate sapwood from red heartwood. The shape of red heartwood in a log is difficult to predict, which complicates the planning of sawmill processing. Log-scanning technologies are not used for beech logs, and one of the reasons for this lies in similar densities of sapwood and red heartwood (Škaljić, 2002; Popadić and Todorović, 2008). Therefore, the processing of beech logs is usually carried out on log band saws.

Separation of sapwood and red heartwood can be done on both primary and secondary machines. In the first case, round sawing or cant sawing is applied, whereas in the second case, live sawing is applied on the primary machine, and the separation is done on rip saw machines. It needs to be said that, in some cases, the presence of red heartwood can be tolerated in sawn timber on a lower-quality side, while in others it is not tolerated at all.

The goal of this research is to determine the influence of the method of primary sawing on the yield and product structure of beech wood.

\section{MATERIAL AND METHOD}

2. MATERIJAL I METODA

Beech sawlogs, 40-49 $\mathrm{cm}$ in diameter and $4 \mathrm{~m}$ long, were used in this research. Such logs provide sufficient red heartwood (Nikolić. 1971; Knoke, 2003) and are, therefore, suitable for comparing the influence of different sawing methods on yield. A total of $45 \operatorname{logs}$ without rot were selected from 42 trees felled in the area of Majdanpek, Serbia. Red heartwood was be round and healthy. Three groups made of 15 logs were prepared for different methods of sawing. These groups were the same regarding the log quality (number and sizes of knots, sweep, shape of cross section, spiral grain, diameter of red heartwood) and dimensions. Average dimensions of the processed logs are shown in Table 1.

Table 1 Average dimensions of processed logs

Tablica 1. Prosječne vrijednosti dimenzija prerađenih trupaca

\begin{tabular}{|l|c|c|c|}
\hline \multirow{2}{*}{ Parameter / Parametar } & \multicolumn{3}{|c|}{ Method of sawing / Način piljenja } \\
\cline { 2 - 4 } & Round / Kružno & Cant / Prizmiranje & Live / U cijelo \\
\hline Thin end log diameter / promjer na tanjem kraju trupca, cm & $44.40(3.146)$ & $43.97(2.266)$ & $43.53(2.649)$ \\
\hline $\begin{array}{l}\text { Red heartwood diameter on thin end of log / promjer lažne } \\
\text { srži na tanjem kraju trupca, cm }\end{array}$ & $20.73(3.727)$ & $19.67(3.913)$ & $19.32(4.46)$ \\
\hline Mid length diameter / promjer na sredini trupca, cm & $45.60(2.971)$ & $44.73(2.463)$ & $45.00(2.803)$ \\
\hline Thick end diameter / promjer na debljem kraju trupca, cm & $50.27(3.788)$ & $48.08(3.131)$ & $48.83(4.308)$ \\
\hline $\begin{array}{l}\text { Red heartwood diameter on thick end of log / promjer } \\
\text { neprave srži na debljem kraju trupca, cm }\end{array}$ & $20.80(5.609)$ & $21.20(3.697)$ & $20.78(4.100)$ \\
\hline Length of log / duljina trupca, $m$ & $4.203(0.174)$ & $4.145(0.099)$ & $4.157(0.098)$ \\
\hline Log volume / volumen trupca, $m^{3}$ & $0.731(0.112)$ & $0.682(0.073)$ & $0.690(0.089)$ \\
\hline
\end{tabular}

Note: values of standard deviation are in parentheses / Napomena: vrijednosti standardne devijacije navedene su u zagradama. 
The measurements (precision of $5 \mathrm{~mm}$ ) taken were: length of $\log (l)$, diameters without bark (thin end - $d$, mid length $-d_{\mathrm{m}}$, thick end - $D$ ), diameters of red heartwood. Thickness of bark was measured with precision of $0.2 \mathrm{~mm}$, and mean value of four sample measurements on each log was used. Values of diameters were calculated as the mean value of two crossmeasurements. All dimensions were rounded to the nearest centimeter, except for the thickness of bark.

Volume of logs without bark $\left(V_{1}\right)$ was calculated according to the formula:

$$
V_{l}=\frac{\left(\frac{d+d_{m}+D}{3}\right)^{2} \pi}{4} \cdot l
$$

Volume of bark was calculated as the difference between volumes of each log with and without bark.

Primary sawing was carried out on a log band saw (Bratstvo, flywheels diameter $1100 \mathrm{~mm}$ ) and a band resaw (Canali, flywheels diameter $1100 \mathrm{~mm}$ ). Logs were sawn into 25 and $50 \mathrm{~mm}$ thick timber, parallel to the central log axis, with thin end forward. Blade parameters were: width - $130 \mathrm{~mm}$ (band saw) and 90 $\mathrm{mm}$ (band resaw), thickness $-1.20 \mathrm{~mm}$ (band saw) and $1.0 \mathrm{~mm}$ (band resaw) and breadth of swage set on one side: $-0.3 \mathrm{~mm}$ (for both blades). Secondary sawing was carried out by the cut-first process on machines with individual cuts, and smaller products were made on a band saw and a cross cut saw. With the exception of sawdust, all wood waste was collected and the mass was measured (precision of $0.5 \mathrm{~kg}$ ).

Round sawing, cant sawing and live sawing were used as the sawing patterns (Figure 1).

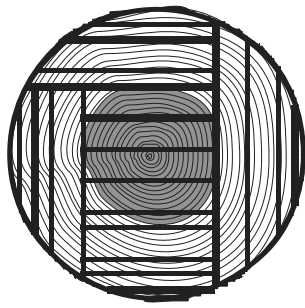

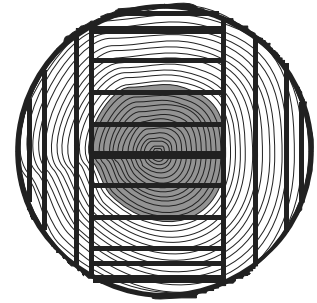

b

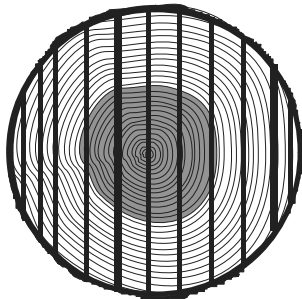

C

Figure 1 Sawing patterns for beech logs with red heartwood ( $\mathrm{a}$ - round sawing, b - cant sawing, c - live sawing) Slika 1. Osnove piljenja za bukove trupce s lažnim srcem (a - kružno piljenje, $b$ - prizmiranje, $c$ - piljenje ucijelo)

Sawing patterns were not predefined but they were adapted according to quality, dimensions and shapes of logs. Separation of red heartwood by round sawing and cant sawing was carried out with a log band saw, and by live sawing separation was carried out on secondary machines.

The main goal of processing was to make products of the highest quality and highest possible value. Un-edged and half edged boards, long and short edged boards, red heart boards, as well as small products (elements for flooring strips, squares, etc.) were produced. The standard applied in this process was SRPS D. C1.022, which is similar to European EN 975-1 standard. The thicknesses of the boards were: $27 \mathrm{~mm}$ (nominal $25 \mathrm{~mm}$ ) and $54 \mathrm{~mm}$ (nominal $50 \mathrm{~mm}$ ). Dimensions of products were measured with the precision of $1 \mathrm{~mm}$, then they were calculated to standard values and the difference in volume was used to determine the actual oversize. Quantitative yield was calculated by dividing the volume of products by the volume of log without bark. Analysis of the timber structure was done for each group of products (unedged timber, edged timber, small products, etc.), calculated as the share in the total volume of timber.

Due to its irregular shape, total volume of large wood waste (slabs, edgings and trimmings) was calculated as a ratio of waste wood mass and wood density.
The average wood density was calculated based on five randomly chosen products from each log, by measuring their mass and dimensions. The volume of sawdust was obtained as a difference between the log volume and sum of product volume and large wood waste volume.

Quantitative yield is a very important indicator of sawmill processing successfulness, but the objective assessment of the effects of production is often made by the value yield. This is often calculated by using the value of production, expressed in a currency per unit of the area or volume (Steele et al., 1993; Popović et al., 2003; Shepley et al., 2004). Such method is simple and practical and it was used as one of the indicators of value yield in this research. Unlike this, Zubčević (1973), Skakić (1985) and Tanušev et al. (2009) calculated the value yield as the product of quantitative and qualitative yield. Value yield calculated in such a manner represents only the value of products but omits some factors, such as entry-value of raw material, which is influenced by numerous factors (Knoke et al., 2006), and the amount of work and energy used in processing. Hapla and Ohnesorge (2005) reported that cutting costs are somewhat below the value of logs. These factors can be included in the calculation of value yield and in this research this was done according to the formula (Šoškić and Popadić, 2010): 


$$
C_{v i}=\frac{C_{q y} \cdot C_{p} \cdot C_{v t}}{C_{v l}} \cdot C_{c p}
$$

where:

$c_{\mathrm{vi}}-$ coefficient of value increase - measure of value yield;

$c_{\text {qy }}-$ coefficient of quantitative yield;

$c_{\mathrm{p}}-$ price coefficient - quotient of average prices of timber and logs;

$c_{v t}-$ mean coefficient of value of timber - measure of real value of timber, compared to a theoretic maximal value;

$c_{\mathrm{vl}}-$ coefficient of value of logs - measure of value of logs, compared to an average value;

$c_{\text {ср }}-$ coefficient of complexity of processing - indirect indicator of the amount of work, determined by the ratio between the average product volume of each log and the average product volume of all logs.

One-way ANOVA and LSD post hoc analysis (SPSS 13.0 software) were used for comparing and determining any significant differences between data groups.

\section{RESULTS AND ANALYSIS}

\section{REZULTATI I ANALIZA}

Structure of sawmill products made of beech wood is shown in Table 2.

The data show that round sawing and cant sawing (tangential methods of sawing) had a higher quantita- tive yield compared to live sawing. Live sawing yield was lower by $3.84 \%$ compared to round sawing, and $3.73 \%$ compared to cant sawing. This is in good agreement with Steele (1984), who reported that the yield of tangential methods of sawing was, on average, higher by $3 \%$ compared to live sawing. However, in this research differences were not statistically confirmed $(F=3.077 ; p=0.057)$ due to high variation within the groups. In general, the quantitative yield was higher than that reported in other papers (Zubčević, 1973; Skakić, 1985; Šoškić and Milić, 2005). The cause for this was that the logs with irregular shape and presence of rot were not used in this research.

Structures of waste were similar regardless of the method of sawing. High variation between logs was found (coefficient of variation of sawdust was up to 20 $\%$, and that of large waste was between $20 \%$ and 30 $\%$ ). The cause of this phenomenon may be a very heterogeneous structure of timber products, which results in different secondary processing. Similar share of sawdust was recorded by Šoškić (1990), who reported the amount of $17 \%$, Popović et al. (2003) $19.7 \%$ and Skakić (1985) reported 9-10\% of sawdust in the first processing phase and another 3-5\% in the second.

The amount of unedged timber was lower in cant sawing than in live and round sawing. However, because of high variations within the groups, the difference was not significant $(F=0.415 ; p=0.663)$. The share of these products mostly depends on the quality of raw material (Popadić and Todorović, 2009), which was equalized in this research. The share of edged timber

Table 2 Structure of yield (\%) depending on the method of sawing

Tablica 2. Struktura iskorištenja (\%) u ovisnosti o načinu piljenja

\begin{tabular}{|c|c|c|c|}
\hline \multirow[b]{2}{*}{ Products / Proizvodi } & \multicolumn{3}{|c|}{ Method of sawing / Način piljenja } \\
\hline & Round / Kružno & $\begin{array}{c}\text { Cant } \\
\text { Prizmiranje }\end{array}$ & Live / Ucijelo \\
\hline $\begin{array}{l}\text { Un-edged timber / neokrajčena građa } \\
\text { Half edged timber / poluokrajčena građa } \\
\text { Total, un-edged and half-edged timber / ukupno, } \\
\text { neokrajčena i poluokrajčena građa }\end{array}$ & $\begin{array}{c}8.69 \\
10.47 \\
19.16(8.28)\end{array}$ & $\begin{array}{c}15.26 \\
1.57 \\
16.83(8.62)\end{array}$ & $\begin{array}{c}19.18 \\
0.00 \\
19.18(7.46)\end{array}$ \\
\hline $\begin{array}{l}\text { Edged timber / okrajčena građa, } L \geq 2 \mathrm{~m} \\
\text { Edged timber / okrajčena građa, } L<2 \mathrm{~m} \\
\text { Total, edged timber / ukupno, okrajčena građa }\end{array}$ & $\begin{array}{c}3.09 \\
9.02 \\
12.11(3.14)\end{array}$ & $\begin{array}{c}5.90 \\
13.69 \\
19.59(3.98)\end{array}$ & $\begin{array}{c}0.18 \\
7.59 \\
7.77(5.71)\end{array}$ \\
\hline Red heart timber / srčanice & $19.67(6.30)$ & $13.97(4.14)$ & $11.85(4.58)$ \\
\hline $\begin{array}{l}\text { Small products (elements for flooring strips, squares, etc.) } \\
\text { sitni proizvodi (popruge, četvrtače itd.) }\end{array}$ & $9.69(3.29)$ & $10.13(3.13)$ & $17.99(3.76)$ \\
\hline Raw material yield / kvantitativno iskorištenje sirovine & $60.63(3.32)$ & $60.52(5.56)$ & $56.79(5.29)$ \\
\hline $\begin{array}{l}\text { Large waste / krupni ostatak } \\
\text { Sawdust / piljevina } \\
\text { Total, Waste / ukupno, ostatak }\end{array}$ & $\begin{array}{c}13.77 \\
15.79 \\
29.56(3.16) \\
\end{array}$ & $\begin{array}{c}15.50 \\
14.70 \\
30.20(6.48) \\
\end{array}$ & $\begin{array}{c}16.31 \\
16.70 \\
33.01(5.11) \\
\end{array}$ \\
\hline Oversize / nadmjera & $9.81(0.89)$ & $9.28(1.20)$ & $10.20(1.04)$ \\
\hline Total / ukupno & 100.00 & 100.00 & 100.00 \\
\hline
\end{tabular}

Note: values of standard deviation are in parentheses / Napomena: vrijednosti standardne devijacije navedene su u zagradama. 
differed in all three methods of sawing ( $F=27.521$; $p=0.000$ ). Cant sawing yielded most edged timber because using this method long edged timber was produced from log sides that contained wood of the highest quality. With the other two methods of sawing, unedged and halfedged timber was produced from these parts. Round sawing produced a lower amount of long edged timber than cant sawing, and live sawing produced almost no such product. Cant sawing also yielded more timber in total compared to the other two methods $(F=4.526 ; p=0.017)$.

Round sawing produced the highest number of red heart boards compared to other methods $(F=9.445$; $p=0.000$ ). According to the applied standard, the minimum width of half edged timber is greater than that of edged timber ( $4 \mathrm{~cm}$ difference). Consequently, in round sawing, turning of logs was often done before the red heartwood was reached, whereas in cant sawing the height of a cant was most often dictated by the diameter of red heartwood. Therefore the width of red heart boards produced by round sawing was wider than of those produced by cant sawing. Fewest red heart boards were recorded by live sawing because they were produced on secondary machines, where a more precise process is applied. A lower share of red heart boards in live sawing than in cant sawing is in a good agreement with the results obtained by Kenjić (according to Škaljić, 2002) who researched the influence of diame- ter of beech logs, diameter of red heartwood, and method of sawing on quantitative yield. He reported that the share of red heart boards was higher than $20 \%$, while other authors (Zubčević, 1973; Skakić, 1985; Šoškić and Milić, 2005) recorded much lower values - around $10 \%$. This difference, along with the above causes, depends on the level of tolerance toward the presence of red heartwood in final products, as well as on the ratio of red heartwood in the log diameter. The quantity of red heart boards is also influenced by their dimensions. Larger boards often contain an area of sapwood, which can be avoided in smaller ones.

Methods of sawing have a significant influence on the quantity of small products $(F=28.188 ; p=0.000)$. Live sawing yielded larger quantities than tangential methods did. In all three methods, the elements for flooring strips were the dominant small products, while squares were produced in a higher amount only by live sawing. In this method, squares were produced from radial boards that, after separation of red heart, had no sufficient width.

Quantitative yield can also be observed, in a relative manner, as the presence of a product volume in the total volume of the product (Figure 2). In such a view, waste and oversize are not represented.

Regarding the product structure, live sawing clearly differed from tangential methods, especially in the quantity of small products. Considerable amount of

- Un-edged and half-edged timber / neokrajčena i poluokrajčena građa Edger timber / okrajčena građa n Red heart timber / srčanice $\square$ Small products / sitni sortimenti

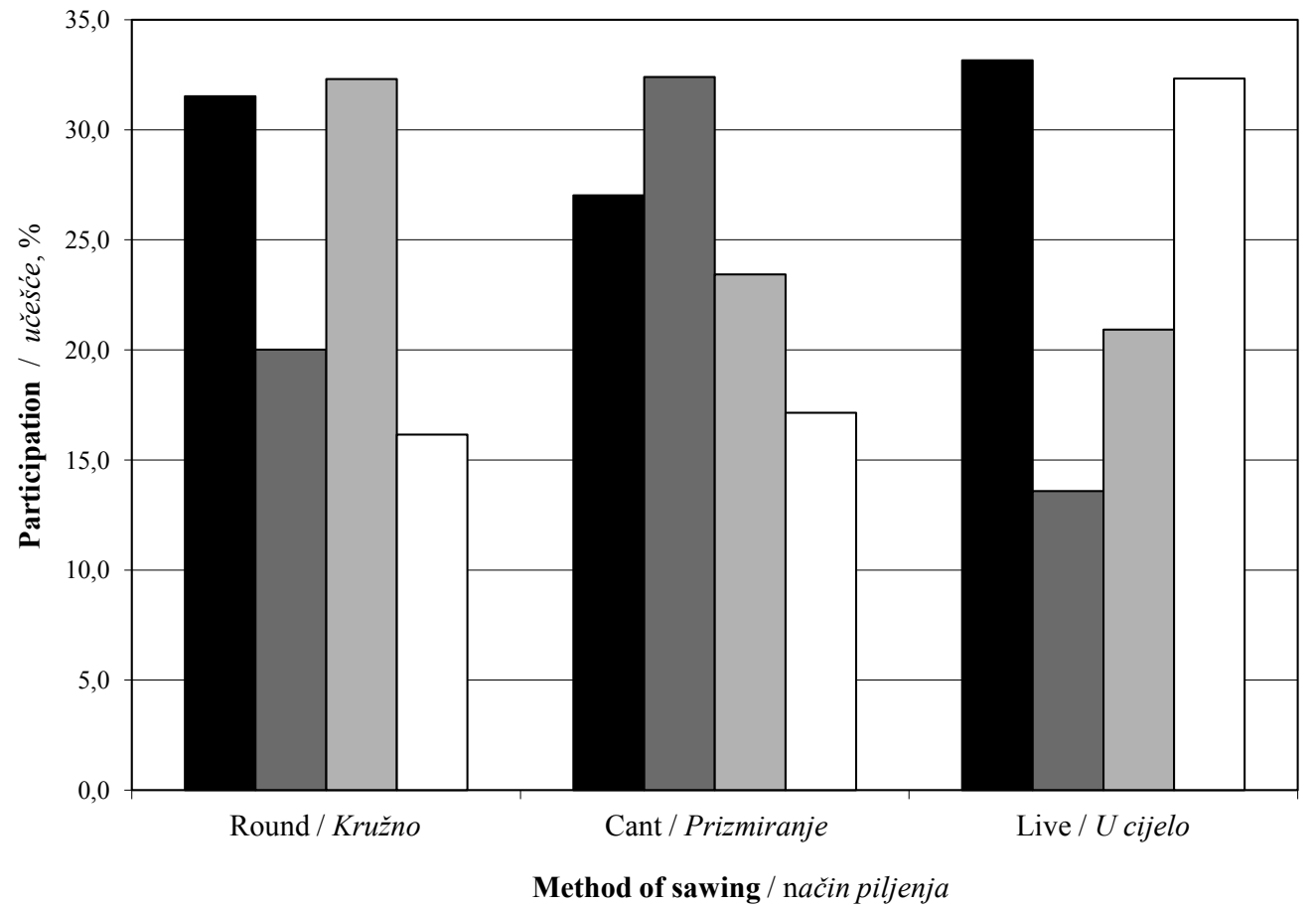

Figure 2 Relative yield of products for different methods of beech logs sawing Slika 2. Struktura piljene građe u relativnom smislu pri različitim načinima piljenja 
small products in live sawing caused the smallest average product compared to the average product of other two methods. The average product volume was: in round sawing $-3.129 \mathrm{~cm}^{3}$, in cant sawing $-2.834 \mathrm{~cm}^{3}$ and in live sawing $-1.769 \mathrm{~cm}^{3}$, which implies that live sawing produced less valuable products, with more work invested.
The share of quarter-, rift- and flat-sawn boards in a log was interesting for analysis because flat-sawn products are most prone to developing deformations during drying. Beech timber made exclusively from sapwood, as the most valuable, is shown in Figure 3.

Regarding the volume of logs, all three methods produced more flat-sawn boards than others. Timber

— Quarter-sawn / radijalne $\square$ Rift-sawn / poluradijalne $\backsim$ Flat sawn / tangencijalne $\square$ Total / ukupno

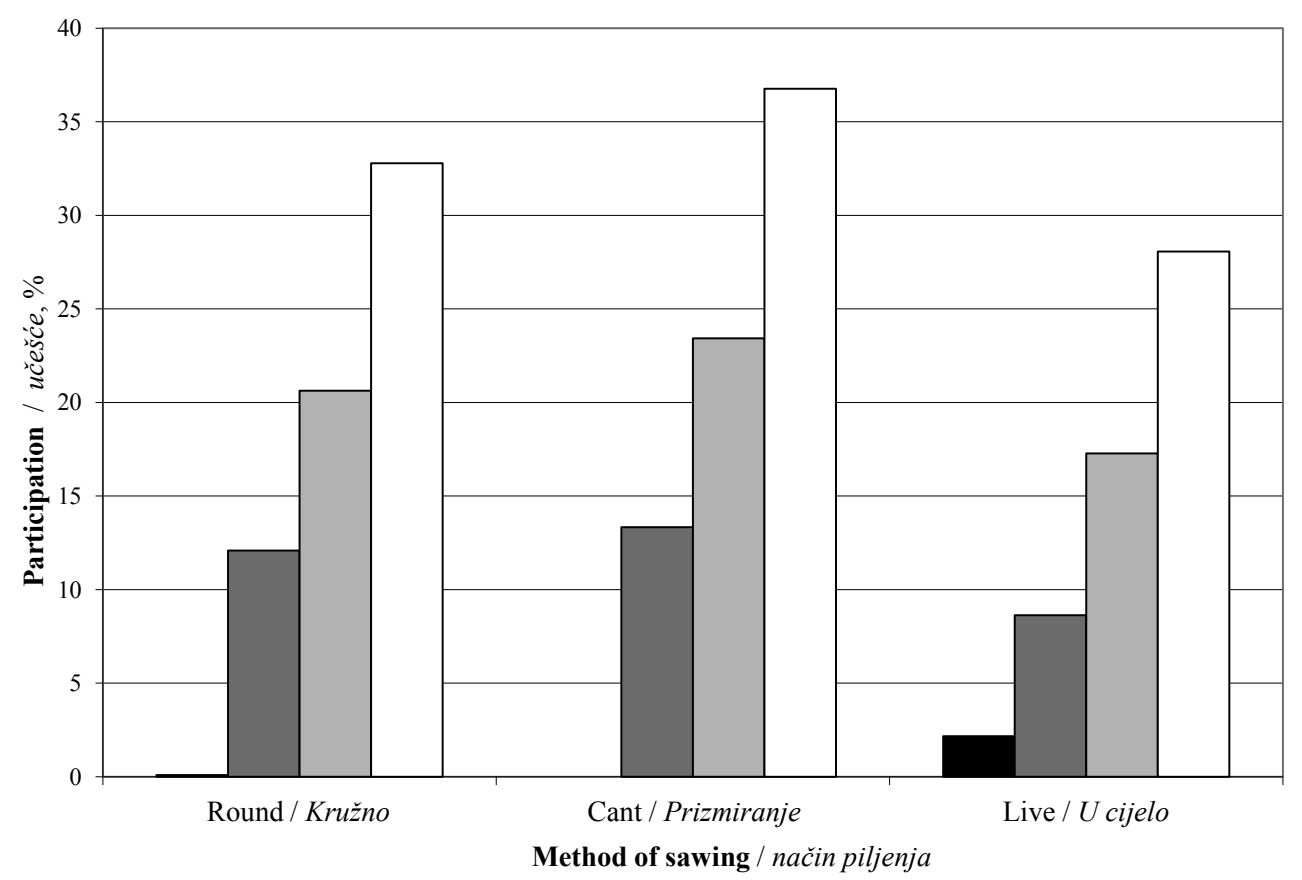

Figure 3 Structure of timber (from sapwood) according to growth ring orientation for different methods of beech logs sawing Slika 3. Struktura piljene građe (od bjeljike) prema položaju godova prirasta pri različitim načinima piljenja bukovih trupaca

structure according to growth ring orientation was similar in round sawing and cant sawing. As expected, flatsawn products were dominant in both tangential methods, as a result of the sawing method and position of quality zones in beech wood, while there were no quarter-sawn boards because from this zone only red heart boards were produced.

Quarter-sawn boards were obtained by live sawing, although in lower quantities than expected. It turned out that parts of quarter-sawn boards left after the separation of red heartwood did not have enough width to be used as timber, so they had to be processed into small products. Rift-sawn boards were produced from the inner, low-quality parts of logs, which, after removing the defects, also yielded small sawmill products. Therefore, the share of rift-sawn boards totaled one-third of timber in all sawing methods.

Quality was determined for large sawmill products: unedged, edged and red heart timber (Figure 4).

Timber of quality class I was dominant in all three methods of sawing with the highest value in round sawing. The share of class III was significantly lower, although the red heart boards were classified as class III. The share of red heart timber in class III was more than $90 \%$ in round and live sawing and around $75 \%$ in cant sawing. Products of class II were least represented in all the methods of sawing.

The effects of different methods of primary logprocessing on quantitative and quality yield could be represented by value yield. It is shown in Table 3,

Table 3 Value yield of beech wood depending on method of sawing

Tablica 3. Vrijednosno iskorištenje bukovine u ovisnosti o načinu piljenja

\begin{tabular}{|l|c|c|c|}
\hline \multirow{2}{*}{ Indicator / Pokazatelj } & \multicolumn{2}{|c|}{ Method of sawing / Način piljenja } \\
\cline { 2 - 4 } & Round / Kružno & Cant / Prizmiranje & Live / Ucijelo \\
\hline $\begin{array}{l}\text { Value of products }\left(€ / \mathrm{m}^{3} \text { of logs) }\right. \\
\text { vrijednost proizvoda }\left(€ / \mathrm{m}^{3} \text { trupaca) }\right.\end{array}$ & 100.60 & 107.29 & 94.11 \\
\hline $\begin{array}{l}\text { Coefficient of value increase }\left(\mathrm{c}_{\mathrm{v}}\right) \\
\text { koeficijent uvećanja vrijednosti }\end{array}$ & 2.62 & 2.58 & 1.40 \\
\hline
\end{tabular}


- Class I / I klasa $₫$ Class II / II klasa $₫$ Class III / III klasa $\square$ Total / Ukupno

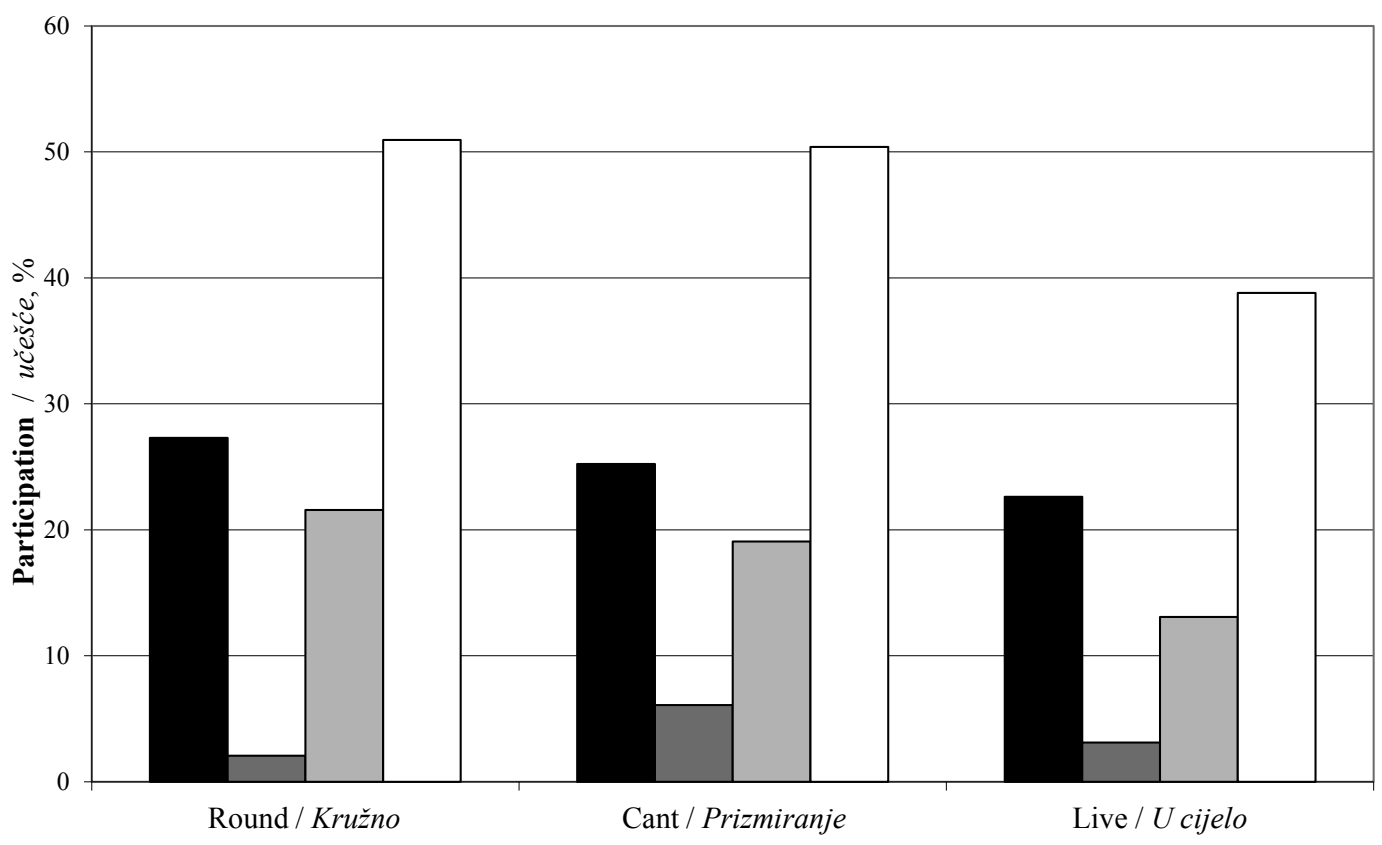

Method of sawing / način piljenja

Figure 4 Quality structure of timber for different methods of beech logs sawing

Slika 4. Kvalitativna struktura piljene građe pri različitim načinima piljenja bukovih trupaca

through values of products per $1 \mathrm{~m}^{3}$ of logs, and the coefficient of value increase $\left(c_{\mathrm{vi}}\right)$.

It is noticeable that the highest value of products per $1 \mathrm{~m}^{3}$ of logs was achieved by cant sawing, and the lowest - by live sawing. However, variations of data were high (standard deviation in cant sawing was around $21 € / \mathrm{m}^{3}$ of $\operatorname{logs}$ ), so the differences between methods of sawing were not proven $(F=2.153$, $p=0.129$ ).

When making the assessment of value yield by value increase coefficient, besides the values of logs and timber dimensions, the amount of work is also taken into account. There is a significant difference between the coefficients of value increase $(F=6.897$, $p=0.003$ ). Post-hoc comparisons showed that there is no difference between tangential methods of sawing, but they had a significantly higher value yield than live sawing. This difference is mainly caused by the coefficient of processing complexity, which amounted to 1.04 for round sawing and 0.94 for cant sawing, but only to 0.59 for live sawing.

\section{CONCLUSION}

\section{ZAKLJUČAK}

Comparing the quantitative and qualitative yields of beech logs sawn by the three methods (round, cant and live), it can be concluded that live sawing yielded the least favorable results, while other two methods yielded similar results. Quantitative yield in round sawing and cant sawing of beech logs was around 60.5 $\%$, whereas in live sawing it was nearly $4 \%$ lower
$(56.8 \%)$. Structures of large and small waste products were equal in all the methods used.

The structure of products was strongly influenced by methods of sawing. It was most favorable in cant sawing, and least favorable in live sawing. Cant sawing yielded most timber, which is especially important for most valued products, that is, long edged timber. Live sawing yielded the highest amount of small sawmill products as compared to other two methods, and the share of red heart boards was the lowest because this product was produced by more precise, secondary machines.

In all three methods, the most frequent boards of all boards made of sapwood were the flat-sawn boards, rift-sawn boards were almost half as frequent and the presence of quarter-sawn boards was negligible, except in live sawing. This was as expected, considering the quality zones in beech logs, as well as the fact that the majority of quarter-sawn products were classified as red heart boards.

Round sawing yielded more timber of quality class I than other methods, but the most favorable structure was reached by cant sawing (production of more valuable products). Therefore, the value yield of these two sawing methods was equal, while live sawing yielded the lowest-value products.

\section{Acknowledgements - Zahvale}

This paper was funded by Ministry of Education, Science, and Technological Development of the Republic of Serbia (TR37008, TR31041 \& III43007). 


\section{REFERENCES}

\section{LITERATURA}

1. Buehlmann, U.; Thomas, R. E., 2002: Impact of human error on lumber yield in rough mills. Robotics and Computer Integrated Manufacturing 18: 197-203.

2. Buehlmann, U.; Thomas, R. E., 2007: Relationship between lumber yield and board marker accuracy in ripfirst rough mills. Holz als Roh- und Werkstoff 65: 43-48. http://dx.doi.org/10.1007/s00107-006-0099-7.

3. Gregić, M., 1982: Iskorištenje niskokvalitetne bukove pilanske oblovine piljenjem tračnim pilama na dva različita načina. Zbornik radova 1976-1980. Vol. II. Istraživanja na području tehnologije masivnog drva, $p$. 1-8. Šumarski fakultet Zagreb.

4. Hapla, F.; Ohnesorge, D., 2005: Modelling of the sawn timber yield of beech logs with regard to the dimension and red heart proportion. Broad spectrum utilisation of wood, Cost Action E44 Conference in Vienna, p.16.

5. Knoke, T., 2003: Predicting red heartwood formation in beech trees (Fagus sylvatica L.). Ecological Modelling 169: 163-179.

6. Knoke, T.; Stang, S.; Remler, N.; Seifert, T., 2006: Ranking the importance of quality variables for the price of high quality beech timber (Fagus sylvatica L.). Ann. For. Sci. 63: 399-413. http://dx.doi.org/10.1051/forest:2006020.

7. Nikolić, S., 1971: Prilog proučavanju veličine i uzroka pojave lažne srčevine bukve na Goču. Glasnik Šumarskog fakulteta 38: 49-59.

8. Petutschnigg, A. J.; Katz, H., 2005: A loglinear model to predict lumber quality depending on quality parameters of logs. Holz als Roh- und Werkstoff 63: 112-117. http:// dx.doi.org/10.1007/s00107-004-0537-3.

9. Popadić, R.; Todorović, N., 2008: Uticaj visokotemperaturnog tretmana na neka fizička svojstva bukovog drveta. Prerada drveta 23: 5-9.

10. Popadić, R.; Todorović, N., 2009: Uticaj načina primarnog piljenja i kvaliteta bukove oblovine na učešće radijalnih, poluradijalnih i tangencijalnih sortimenata. Prerada drveta 28: 28-34.

11. Popović, Z.; Šoškić, B.; Todorović, N., 2003: Iskorišćenje bukovog drveta pri jednofaznoj pilanskoj preradi. Prerada drveta 3-4: 17-21.

12. Prekrat, S.; Župčić, I.; Ištvanić, J., 2004: Neprava srž bukovine - prednost u racionalnoj preradi i primjeni. Drvna industrija 55(2): 91-96.

13. Shepley, B. P.; Wiedenbeck, J.; Smith, R. L., 2004: Opportunities for expanded and higher value utilization of No. 3A Common hardwood lumber. For Prod J 54(9): 77-85.

14. Skakić, D., 1985: Iskorišćenje bukove sirovine pri izradi elemenata za stolove i stolice. Doktorska disertacija. Šumarski fakultet u Beogradu.
15. Steele, P. H., 1984: Factors Determining Lumber Recovery in Sawmilling. Gen. Tech. Rep. FPL-39. p. 8.

16. Steele, P. H.; Wagner, F. G.; Kumar, L.; Araman, P. A., 1993: The Value Versus Volume Yield Problem for LiveSawn Hardwood Sawlogs. For Prod J 43(9): 35-40.

17. Tanušev, V.; Ištvanić, J.; Moro, M.; Butković, J., 2009: Iskorištenje pri izradi grubih drvnih elemenata iz bukovih (Fagus sylvatica L.) trupaca manjih promjera i niže kvalitete. Šumarski list 9-10: 483-492.

18. Škaljić, N., 2002: Simulirano piljenje kvalitetnih bukovih trupaca u zavisnosti od položaja i veličine neprave srži. Magistarski rad. Mašinski fakultet Univerziteta u Sarajevu.

19. Šoškić, B., 1990: Prilog rešavanju problema otpadaka u preradi drveta. Glasnik Šumarskog fakulteta 71-72: 4352 .

20. Šoškić, B.; Milić, G., 2005: Uticaj kvaliteta bukovih trupaca na iskorišćenje pri pilanskoj preradi. Prerada drveta 12: $15-22$.

21. Šoškić, B.; Popadić, R., 2007: Uticaj kvaliteta bukove oblovine na strukturu glavnih i sporednih proizvoda $u$ pilanskoj preradi. Prerada drveta 20: 11-16.

22. Šoškić, B.; Popadić, R., 2010: Izračunavanje vrednosnog iskorišćenja oblovine u pilanskoj preradi drveta metodom koeficijenta uvećanja vrednosti. Prerada drveta 3031: 24-27.

23. Šoškić, B.; Popović, Z., 1992: Varijacija učešća i svojstava kore nekih domaćih vrsta drveća. Drvarski glasnik 1: 3-9.

24. Wernsdörfer, H.; Constant, T.; Mothe, F.; Badia, M. A.; Nepveu, G.; Seeling, U., 2005: Detailed analysis of the geometric relationship between external traits and the shape of red heartwood in beech trees (Fagus sylvatica L.). Trees 19: 482-491. http://dx.doi.org/10.1007/ s00468-005-0410-y.

25. Zubčević, R., 1973: Uticajni faktori pri izradi grubih obradaka iz niskokvalitetne bukove pilanske sirovine. Disertacija. Mašinski fakultet, Sarajevo.

26. *** EN 975-1 2009: Sawn timber - Appearance grading of hardwoods - Part 1: Oak and beech.

27. *** SRPS D.C1.022 1982: Rezana bukova građa.

\section{Corresponding address:}

Assist. RANKO POPADIĆ, MSc.

University of Belgrade

Faculty of Forestry

Kneza Višeslava 1, Belgrade, SERBIA

e-mail: ranko.popadic@sfb.bg.ac.rs 